\title{
The Effect of M-Banking Service Quality and Customer Perceived Value to Satisfaction and Loyalty of Bank XYZ Customers
}

\author{
Elvriawati Tumewah, Juniarta, Yonathan Kurniawan
}

\begin{abstract}
Many banks in Indonesia have been conducting surveys to customers related to services at branch offices (Branch Service Quality) and Customer Engagement with results that continue to growevery year. With the advancement of digital technology, counter services have begun to shift to digital channels, especially mobile banking. Existing research related to the use of mobile banking uses e-servquality more often, which is generally used in research to see the excellence of services in internet banking, online shops, and digital marketplaces. Therefore, we consider it is necessary to carry on a research about the effect of mobile banking service quality on customer satisfaction and loyalty, the effect of customer perceived value on customer satisfaction and loyalty, and the effect of customer satisfaction with customer loyalty. The research was conducted by setting a sample of Bank XYZ customers who use Bank XYZ mobile banking, the total is 505 respondents. Structural equation modeling was used to carry outconfirmatory factor analysis and path analysis. From the results, it can be seen that mobile banking service quality and customer perceived value have a significant effect on customer satisfaction, but no significant effect on customer loyalty. Meanwhile, customer satisfaction has a significant effect on customer loyalty.
\end{abstract}

Keywords: Customer Loyalty, Customer Perceived Value, Customer Satisfaction,Mobile Banking Service Quality

\section{INTRODUCTION}

Satisfaction of a customer is an important thing for sustainability of a company. Customer satisfaction is a degree when the needs, desires, and expectations of customers can be met. The result would be a repurchase or continued devotion.Customer Satisfaction will appearafter someone is comparing the performance/product resultsto the expected performance, whether it is a feeling of pleasure or disappointment [1].A customer, if satisfied with the value provided by the product or service provided, is very likely to be a customer for a long time [1].Based on data from the Financial Services Authority (OJK), there was a significant growth for users who usee-banking (SMS banking, phone banking, internet banking and mobile banking) in Indonesia which escalated to 50.4 million customers in 2016 from 13.6 million customers in 2012.

Revised Manuscript Received on February 05, 2020.

* Correspondence Author

ElvriawatiTumewah*, Magister of Management Business Management, Binus University, Jakarta, Indonesia. Email: elvritumewah@yahoo.com

Juniarta, Magister of Management Business Management, Binus University, Jakarta, Indonesia. Email: juniarta28@yahoo.co.id

Yonathan Kurniawan, Magister of Management Business Management, Binus University, Jakarta, Indonesia. Email: yonathan_kurniawan@yahoo.com

(c) The Authors. Published by Blue Eyes Intelligence Engineering and Sciences Publication (BEIESP). This is an open access article under the CC BY-NC-ND license (http://creativecommons.org/licenses/by-nc-nd/4.0/)
More than $50 \%$ of e-banking users definitely have a significant mobile banking facility. Based on research conducted by Pricewaterhouse Coopers Indonesia (PwCI), the number of smartphone users in 2018 reached 50 million users.

The increase in mobile banking users is also influenced by advances in digital technology, and lifestyle changes that prioritize practicality and high mobility [2].

In addition to the excellence of service from mobile banking, another thing that can affect customer satisfaction and loyalty in using mobile banking is how someone compares the financial benefits and process benefits to change the behavior of banking transactions using mobile banking [3].Customers who feel the process of moving their transaction behavior using mobile banking will provide added value/benefits compared to the cost of the move will be delighted and devoted to the mobile banking service [2]. The combination of good quality mobile banking services and how a customer switches to using mobile banking because they see more profit (customer perceived value) will determine customer satisfaction and loyalty, which in turn will determine the sustainability of the bank's business [4].

Research related to service quality has been carried out and produced many influential factors [5]-[6], including the E-Servqual model which was developed to examine the excellence of digital services [6]. This model is more often and more precisely used in research on the excellence of internet banking services, market places, and online shops, but is still not used to see the quality of services when using mobile banking. Adjustments are needed red to the characteristics of mobile banking services that are different from other digital services such as online shops, digital market places, and internet banking [7].

Many banks realize that the service quality factor is very influential on customer satisfaction as one of the factors to win the banking competition. Most bank transaction in Indonesia has been switching to mobile banking, for example customers of Bank XYZ mobile banking has experienced significant growth, with 7 million mobile banking users, and 15-17 million transactions daily [8]. The number of mobile banking transactions at Bank XYZ also experienced significant growth compared to other transactions such as ATMs, Internet Banking, or Branch Banking. Mobile banking transactions at Bank XYZ grew by $51.50 \%$ in 2018 compared to 2017, internet banking transactions grew by $15.80 \%$, while transactions using ATMs at Bank XYZ decreased by $-0.1 \%$,

Published By:

Blue Eyes Intelligence Engineering

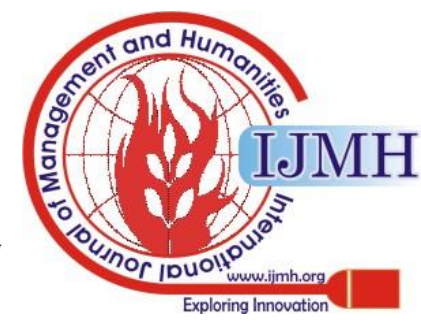


and transactions at branches also experienced a decrease of $-2.90 \%$. With the growth in the number of transactions which is quite large if likened with other banking transaction facilities, it showed that the number of complaints also shows the highest number for m-banking products at Bank XYZ, which is $58.46 \%$ of the total complaints over e-banking facilities at Bank XYZ [8].

This is why this research was conducted, to see whether customers who have used mobile banking have been delighted with the excellence of mobile banking services and whether delighted customers are also devoted to the bank. This research can also provide information related to features, services, speed, security, and other factors in the quality of mobile banking services that can affect customer satisfaction and loyalty of mobile banking users to a bank, so many banks in the future when developing mobile banking must pay attention to these matters to support customer satisfaction and loyalty in using mobile banking.

\section{LITERATUREREVIEW}

\section{A. Mobile Banking Service Quality}

Service Quality is the level of distinctness between customers' service perceptions and expectations[9].Mobile Banking Service Quality comprised of 4 dimensions [7], namely Efficiency \& Convenience, Assurance \& Security, Reliability, and Responsiveness. The Efficiency \& Convenience Dimension in Mobile Banking Service Quality discusses the use of online services, how the speed and ease of the facilities provided that can help consumers in the transaction [9]-[10]. The Reliability dimension in Mobile Banking Service Quality discusses the execution of services carried out online related to the fulfillment of requests from consumers, such as reliable, trustworthy, accessible anytime and anywhere[9]-[10].The Assurance \& Security dimension in Mobile Banking Service Quality discusses the level of security, both security in transactions and security in managing \& storing consumer data [9]-[10]. The Responsiveness Dimension in Mobile Banking Service Quality discusses how an online service can deal effectively with a problem and how a feedback can be given to consumers [9]-[10].

\section{B. Customer Perceived Value}

Customer Perceived Value is the value formed from the customer's perception of the value/benefit to be obtained compared to the sacrifice/cost that needs to be incurred [11]. Customer Perceived Value can directly affect customer loyalty and even so can affect customer satisfaction [2]-[3]. In services, a customer will compare what is obtained (profit) and what must be given (costs) to obtain a service [11]. In the context of the use of mobile banking, the value desired by the customer can be defined as the level of profit that can be provided by the use of mobile banking to its users when carrying out their banking activities [10]. While related factors that involve sacrifice in monetary terms in the use of mobile banking, is how much money must be paid/issued to use mobile banking services or migration from the old system/method [11]. While related factors that involve sacrifice in non-monetary terms in usingmobile banking are related to risk, time, and convenience [11].

\section{Customer Satisfaction}

Customer satisfaction is the ability of a company to meet the business, psychological, and emotional needs of its customers [1], [12]. The satisfaction of a banking customer depends on fulfillment of the customer's expectations affiliated to the services provided by a bank [13]. The main factor that determines consumer satisfaction is consumer discernment of service quality [13]. A customer's contentment in doing transactions in a bank will affect the loyalty and profitability of the bank, customer satisfaction is directly proportional to profit received by banks [12] Customer satisfaction has a positive relationship with customer loyalty, so that it can increase the portfolio of products/facilities/services owned by customers, reduce costs, and increase bank profits [4], [14]. The positive correlation among customer satisfaction and financial performance of a bank makes matters regarding customer satisfaction very important to be considered by bank management [15]. The satisfaction of a customer in making transactions at a bank tends to be more easily anticipated and measured, due to human-to-human meetings (bank employees and customers). The challenge in the banking world is to design systems and measurements related to the level of customer satisfaction that conducts transactions using mobile banking [16]. Customers who are satisfied to transact in banks, both online and offline, will affect the level of loyalty, and ultimately will affect the financial performance of the banking itself. For this reason, it is necessary to evaluate the satisfaction degree of a customer transacting at the bank, especially for banking services that are not face to face with using mobile banking [2].

\section{Customer Loyalty}

Customer loyalty is a behavioral tendency of customers to use a product or service many times, due to feelings attached to the product/service/person/company [17]. The commitment of a customer to do repurchases of certain products/services is a form of loyalty [17]. Customer loyalty can be circumscribed as the possibility of a customer making repeated purchases and their willingness to be a partner for a company providing goods or services [1]. Being a partner means the customer is willing to make purchases of goods or services in increasing numbers, giving positive recommendations to others to buy the goods or services, and is willing to provide feedback/input/adviceto the company on goods/services/operational processes by the company. Marketing costs will be reduced in line with the increased customer loyalty, and can also increase new customers as a result of these loyal customer references [18]-[19]. Conversely, if a customer becomes dissatisfied when making a transaction, it will have an effect on the bank's performance, namely bank profits that decline due to customers who move [1]. There are at least 4 indicators stating that a customer has been considered a loyal customer, including: repeat purchase transactions, recommending products/services purchased to other parties, using other products/services offered by the company, not affected by product/service offers from other companies (competitors) [13].

Published By:

Blue Eyes Intelligence Engineering

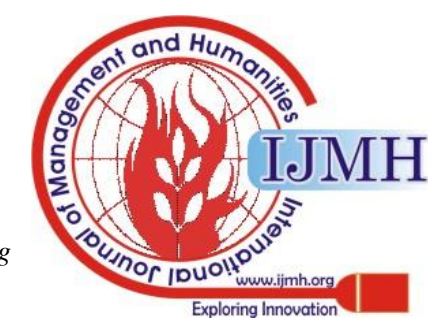




\section{HYPOTHESIS}

There are 4 interesting variables to examine the relationship between them, where there are independent variables and dependent variables that overall will be researched whether there is a significant effect or not between the relationship of these variables.

There are some factors that impacted customer satisfaction, such as Efficiency \& Convenience, Assurance \& Security, Reliability, Responsiveness. Each factor has each dimension that forms themselves which can be measured to determine its effect on customer satisfaction [7]. Factors in Service Quality have an outcome on customer satisfaction and loyalty in using mobile banking in Iran, by looking at several factors encompassing reliability, responsiveness, empathy and tangibles [20].The research which was conducted indicated that these factors had a positive and strong impact on customer satisfaction in using mobile banking in Iran. Mobile banking users are described as a party that is very concerned about the quality of its services, that is what determines whether a customer will be satisfied and continue to use mobile banking or not. Efficient and trustworthy services, security, responsiveness, and ease of use that are part of E-Servqual have a positive and significant impact on customer satisfaction in using digital banking [21]. It can be seen that the quality of services both in internet banking and mobile banking has a positive and substantialoutcome on customer satisfaction and loyalty in using digital banking facilities. It is important to know whether there is a significant effect between Mobile Banking Service Quality on customer satisfaction and customer loyalty using the mobile banking facility.

$H_{1}$ : Mobile Banking Service Quality has a significant effect on Customer Satisfaction

$\mathrm{H}_{2}$ : Mobile Banking Service Quality has a significant effect on Customer Loyalty

There is a direct effect among customer perceived value to customer satisfaction and customer loyalty [3]. There are two dimensions of customer perceived value namely benefits factors and sacrifice factors. Benefit factors contain the value desired by their customers, while sacrifice factors contain monetary (service costs) and non-monetary considerations (time, energy) [3]. Customer perceived value can provide a direct, positive, and substantialoutcomeon customer satisfaction in using digital banking services, especially internet banking and mobile banking. For mobile banking, we want to know whether there is any significant effects between customer perceived value to customer satisfaction and customer loyalty [2].

\section{$\mathrm{H}_{3}$ : Customer Perceived Value Mobile Banking has a significant effect on Customer Satisfaction \\ $\mathrm{H}_{4}$ : Customer Perceived Value Mobile Banking has a significant effect on Customer Loyalty}

In several studies related to customer satisfaction and loyalty, there is a positive effect among customer satisfaction and customer loyalty [18]-[19]. Satisfied customers tend to do repetitive activities to consume or even give references to friends over positive experiences that have been experienced [22]. Customer satisfaction is a mediating variable between service quality and customer loyalty. Customer satisfaction is affected by the excellence of service, and customer loyalty is significantly affected by customer satisfaction. Customers who feel satisfied tend to be devoted customers and will not move to other competitors, as long as they are served with good quality service [22]. Repeated purchase transactions, activities recommending products/ services purchased to other parties, using other products/services offered by the company, not affected by products/services offered from the competitors are indicators of customers who are satisfied with transactions and currently show condition as a loyal customer [13]. For this reason, we also want to know whether there is a correlation among customer satisfaction in the transaction with mobile banking and loyalty.

$\mathrm{H}_{5}$ : Customer Satisfaction has a significant effect on Customer Loyalty

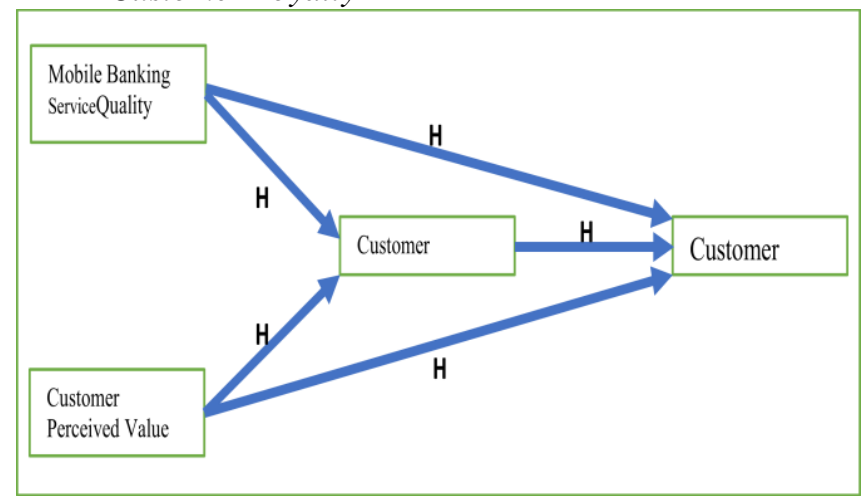

Fig. 1. Research Model

\section{PROPOSED RESEARCH DESIGN}

\section{A. Approach, Purpose, and Strategy}

This research aims to see whether the independent variable (mobile banking service quality and customer perceived value) significantly affects customer satisfaction and loyalty in mobile banking services at Bank XYZ, in addition to whether customer satisfaction in using mobile banking has a substantial effect on customer loyalty. This study is conducted to investigate the significant relationship between these variables in the research model.

The field of study in this research is Social Field with Inferential research level, in the form of drawing conclusions from hypothesis testing. The factors that are in the variables that can affect the use of mobile banking will be examined to see whether it has a substantial effect on customer assurance and commitment in using mobile banking. To get the value of each element in the mobile banking usage variable, the research strategy design that will be used is Survey research, with the method of collecting data by distributing questionnaires.The survey strategy can collect quantitative and qualitative data from the types of questions asked, where sampling will be carried out on Bank XYZ customers who have used mobile banking. The approach taken in this study is a cross sectional approach, which uses different subjects at the same time.

Published By:

Blue Eyes Intelligence Engineering

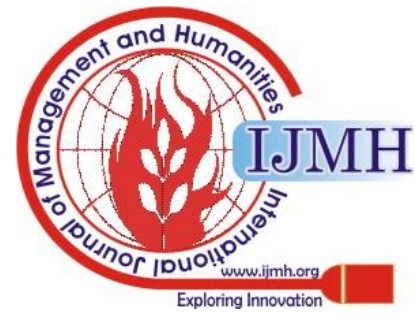


The Effect of M-Banking Service Quality and Customer Perceived Value to Satisfaction and Loyalty of Bank XYZ Customers

The research will be conducted under normal conditions and without setting (non-contrived) with individual units of analysis. Sampling is conducted on Bank XYZ customers who have used mobile banking, so it is possible to take samples cross-sectionally, non-contrivedly, and individually per customer.

If seen from the results to be obtained, this research is basic research, to find out whether a theory or previous research can be used in different conditions. This study is more directed to ascertain whether the correlation among mobile banking service quality and customer perceived value has a substantialoutcome on customer satisfaction and loyalty, and whether the customer satisfaction variable has a substantial outcome on customer loyalty, related to the use of mobile banking.

\section{B. Data Collection Techniques and Methods}

Technique of sending and collecting questionnaires using electronic/online questionnaires was conducted in this research. This technique is easier and faster. It only requires a cover letter to invite people to fill in the survey via a link and a data base to store the answers and software to analyze the answers. The list of questionnaires can be seen on appendix.

The number of sample that was taken is 505 Bank XYZ customers who use mobile banking. The sampling technique used is Non Probability Sampling because only customers who have used mobile banking can fill out the survey questionnaire. The questionnaire distributed will contain elements of the variables contained in this research, namely mobile banking, service quality, customer perceived value, customer satisfaction, and customer loyalty.

\section{Proposed Statistical Analysis}

After the overall data obtained from the questionnaires, the data will be tested by conducting a validity and reliability test. The tests are carried out to see whether the amount of data collected in each dimension is valid and reliable to be forwarded to the next data processing and whether the data collected is correct in accordance with existing conditions, and the variance consistently represents a sample of data taken on the population. Valid and reliable data will be processed to find out whether there is a substantial correlation among independent variables with customer satisfaction and customer loyalty in using mobile banking (dependent variable).

Variables measurement analysis will use PLS Structural Equation Modeling (PLS SEM) to determine the correlation among the variables. Measurement Model (CFA) with convergent validity factor loading $>0.5$.Leverage Variance Extracted (AVE) with a value $>0.5$, with composite reliability $>$ 0.6. Structural Model, with a minimum bootstrap sample 5000, with a T-value $>1.96$.

\section{RESULTS \& DISCUSSION}

From the number of samples obtained as many as 505 respondents of Bank XYZ customers who use Bank XYZ Mobile Banking, obtained the following data set:
Table I (a). Qualitative Data of Respondents

\begin{tabular}{|c|c|c|c|}
\hline Details & & Total & $\begin{array}{c}\text { Percentage } \\
(\%)\end{array}$ \\
\hline \multirow[t]{2}{*}{ Sex } & Male & 159 & $31.5 \%$ \\
\hline & Female & 346 & $68.5 \%$ \\
\hline Last & $<=$ High School & 71 & $14.1 \%$ \\
\hline \multirow[t]{4}{*}{ Education } & Diploma & 34 & $6.7 \%$ \\
\hline & $\mathrm{S} 1$ & 369 & $73.1 \%$ \\
\hline & $\mathrm{S} 2$ & 28 & $5.5 \%$ \\
\hline & S3 & 1 & $0.4 \%$ \\
\hline \multirow[t]{5}{*}{ Age } & $<=18$ Years old & 3 & $0.6 \%$ \\
\hline & $\begin{array}{l}18-25 \text { years } \\
\text { old }\end{array}$ & 74 & $14.7 \%$ \\
\hline & $\begin{array}{l}26-35 \text { years } \\
\text { old }\end{array}$ & 153 & $30.3 \%$ \\
\hline & $\begin{array}{l}36-45 \text { years } \\
\text { old }\end{array}$ & 128 & $25.3 \%$ \\
\hline & $>46$ years old & 147 & $29.1 \%$ \\
\hline \multirow[t]{6}{*}{ Occupation } & Students & 14 & $2.8 \%$ \\
\hline & Housewife & 42 & $8.3 \%$ \\
\hline & Worker & 374 & $74.1 \%$ \\
\hline & Professional & 12 & $2.4 \%$ \\
\hline & Entrepreneur & 60 & $11.9 \%$ \\
\hline & Not Working & 3 & $0.6 \%$ \\
\hline Duration & $<1$ year & 9 & $1.8 \%$ \\
\hline being & 1 -3 years & 51 & $10.1 \%$ \\
\hline customer & 4-6 years & 64 & $12.7 \%$ \\
\hline Bank XYZ & $>6$ years & 381 & $75.4 \%$ \\
\hline
\end{tabular}

Table I (b). Qualitative Data of Respondents

\begin{tabular}{|c|c|c|c|}
\hline Duration of & $<1$ year & 39 & $7.7 \%$ \\
\hline using Bank & 1 -3 years & 157 & $31.1 \%$ \\
\hline XYZm- & 4- 6 years & 111 & $22.0 \%$ \\
\hline banking & $>6$ years & 198 & $39.2 \%$ \\
\hline Frequency of & $<=1 \mathrm{x}$ & 12 & $2.4 \%$ \\
\hline use of Bank & $2-5 x$ & 93 & $18.4 \%$ \\
\hline $\mathrm{XYZ} \quad \mathrm{m}-$ & $6-10 x$ & 135 & $26.7 \%$ \\
\hline $\begin{array}{l}\text { banking/ } \\
\text { month }\end{array}$ & $>10 x$ & 265 & $52.5 \%$ \\
\hline Use of m- & Yes & 157 & $31.1 \%$ \\
\hline $\begin{array}{ll}\text { banking } & \text { other } \\
\text { than } & \text { Bank } \\
\text { XYZ } & \end{array}$ & No & 348 & $68.9 \%$ \\
\hline Duration of & $<1$ year & 38 & $24.2 \%$ \\
\hline using & $1-3$ years & 72 & $45.9 \%$ \\
\hline banking & 4-6 years & 23 & $14.6 \%$ \\
\hline another bank & $>6$ years & 24 & $15.3 \%$ \\
\hline Frequency of & $<=1 \mathrm{x}$ & 39 & $24.8 \%$ \\
\hline use of m- & $2-5 x$ & 70 & $44.6 \%$ \\
\hline banking at the & $6-10 x$ & 23 & $14.6 \%$ \\
\hline other bank & $>10 x$ & 25 & $15.9 \%$ \\
\hline
\end{tabular}

Female respondents were more than male respondents that is $68.50 \%$

Published By:

Blue Eyes Intelligence Engineering

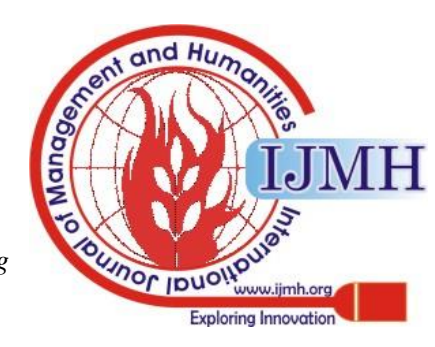


compared to $31.50 \%$. $73.10 \%$ of the respondents graduated from S1 so it can be said that the respondents of mobile banking users are quite educated. More than $80 \%$ of respondents are aged over 26 years, with most occupation is worker (74.10\%) $11.90 \%$ working as entrepreneurs, and the rest are students, housewives, professionals, and not working. Most respondents are existing customers who have been customers for more than 6 years $(75.40 \%)$ and only $1.80 \%$ are new customers under 1 year.

The interesting thing is that even though respondents who have been customers for more than 6 years are $75.40 \%$, the number of mobile banking users over 6 years is only $39.20 \%$ and $31.10 \%$ just using mobile banking for the past 1-3 years. This is in line with advances in digital technology. Smartphone, that becomes mobile banking access devices, had an increased in the terms of users. There was a change in behavior in transactions from customers, where the use of cashless transactions increased, as seen from the increasing numbers of mobile banking and internet ATMs and branches declined. 52.50\% of mobile banking user respondents also actively engaged in transactions above 10 transactions monthly, indicating that mobile banking has been accepted and is one of the banking transaction tools that is used quite actively for transactions.

Out of 505 repondents, there were $31.10 \%$ respondents who use mobile banking facilities at banks other than Bank XYZ. When viewed from the time using the mobile banking facility, $45.90 \%$ have only used it for the past 1-3 years. This result shows the same conditions as Bank XYZ, where the average mobile banking user has only used it for the past 1-3 years. It can be said that the factors determining the use are not from the promotion of the bank, but rather because of transaction tools (smartphones) that are increasingly easy to obtain and easy to use as well as changing customer transaction behavior into cashless. Of the respondents who used the other mobile banking facilities, it turns out that $15.90 \%$ repondents actively using other banks' mobile banking above 10 transactions permonth, while the largest is $44.60 \%$ using 2-5 transactions permonth. This shows that Bank XYZ's mobile banking is still a mainstay of customers in the transaction with greater active use.

\section{A. Validity and Reliability Test}

From the results of the questionnaires which measure the variables of mobile banking service quality, perceived value, customer satisfaction, and customer loyalty, the validity test of the four variables was conducted.

\begin{tabular}{lc}
\multicolumn{2}{l}{ Table II. AVE (Validity Test) } \\
\hline CPV & AVE \\
LOY & 0,665533 \\
MBSQ & 0,855475 \\
SAT & 0,594621 \\
\hline
\end{tabular}

Table IIshows the AVE value for all variables exceeds 0.5 ( $>0.5$ ), which indicates that all variables (mobile banking service quality, perceived value, customer satisfaction, and customer loyalty) are also valid and can be used for the nextresearch. After the validity test is performed, the banking transactions at Bank XYZ, while transactions at

reliability test is then performed to determine whether the existing dimensions are reliable for the variable. The reliability test was performed by looking at the value of Composite Reliability and Cronbach's alpha.

Table III. Composite Reliability and Cronbach's Alpha (Reliability Test)

\begin{tabular}{lcc}
\hline & Composite Reliability & Cronbach's Alpha \\
\hline CPV & 0,946866 & 0,936475 \\
LOY & 0,959470 & 0,943636 \\
MBSQ & 0,963098 & 0,958888 \\
SAT & 0,963346 & 0,949165 \\
\hline
\end{tabular}

From table III, it appears that the overall value of the test results for each variable exceeds $0.7(>0.7)$. This means that all variables (mobile banking service quality, perceived value, customer satisfaction, and customer loyalty) are reliable, trustworthy, and can be used for further testing.

\section{B. T Test Results}

The $\mathrm{T}$ test results are as follows:

Table IV. T Test

\begin{tabular}{lc}
\hline & T Statistics \\
\hline CPV -> LOY & 0,054894 \\
CPV -> SAT & 2,281183 \\
MBSQ -> LOY & 1,054204 \\
MBSQ -> SAT & 3,237364 \\
SAT -> LOY & 4,428784 \\
\hline
\end{tabular}

There are 2 T-Statistics values which have values below 1.96 (<1.96), namely Customer Perceived Value and Customer Loyalty (0.05) andMobile Banking Service Quality and Customer Loyalty (1.05). The correlationamong other variables is $>1.96$, namely Customer Perceived Value and Customer Satisfaction (2.28), Mobile Banking Service Quality and Customer Satisfaction (3.24), and Customer Satisfaction and Customer Loyalty (4.43 ).

This shows that $\mathrm{H}_{2}$ (Mobile Banking Service Quality has a substantial outcome on Customer Loyalty) and $\mathrm{H}_{4}$ (Mobile Banking Customer Perceived Value has a substantial outcomeon Customer Loyalty) is rejected, which means Mobile Banking Service Quality and Customer Perceived Value have no substantial outcomeon customer loyalty.

Meanwhile, $\mathrm{H}_{1}$ (Mobile Banking service Quality has a substantial outcomeon customer satisfaction), $\mathrm{H}_{3}$ (Mobile Banking Customer Perceived Value has a substantial outcomeon Customer Satisfaction), $\mathrm{H}_{5}$ (Customer Satisfaction has a substantial outcomeon Customer Loyalty) is accepted, which means Mobile Banking Service Quality and Customer Perceived Value have a substantial outcome on customer satisfaction, and Customer Satisfaction also has a substantial outcome on customer loyalty.

When viewed from the independent variable of Mobile Banking Service Quality (Hypothesis 1), it appears that Mobile Banking Service Quality has asubstantial effect on Customer Satisfaction. This means that the dimensions of Efficiency \& Convenience,

Published By:

Blue Eyes Intelligence Engineering

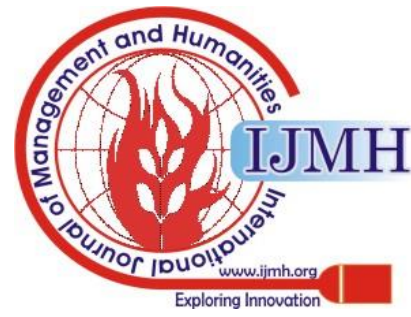


Assurance \& Security, Reliability, Responsiveness have a substantial effect on customer satisfaction in using Bank XYZ mobile banking.

Factors such as speed, convenience, fulfillment of desires and needs, transaction and data security, and handling when affected by a problem determine whether a customer is satisfied or not in using Bank XYZ mobile banking services, and Bank XYZ mobile banking services are proven in terms of service quality to be able to give satisfaction to its customers.

When viewed from the other independent variables of Mobile Banking Customer Perceived Value (Hypothesis 3), it appears that Mobile Banking Customer Perceived value has substantial outcome on Customer Satisfaction.Benefit Factors in the form of values desired by customers, and sacrifice factors in the form of monetary considerations (service costs) and non monetary (time and energy) have a substantial effect on customer satisfaction in using Bank $\mathrm{XYZ}$ mobile banking. In this case, the benefit factors and sacrifice factors in using Bank XYZ mobile banking show that they have provided contentment to their customers.

In Customer Loyalty dependent variable, when viewed from the independent variable of Mobile Banking Service Quality (Hypothesis 2), it appears that Mobile Banking Service Quality does not have a substantial outcome on Customer Loyalty. The independent variable of Mobile Banking Service Quality only has a significant effect on customer satisfaction, but does not have a direct and substantial effect on customer loyalty in using Bank XYZ mobile banking, meaning that factors in Mobile Banking Service Quality cannot significantly affect customer loyalty.

In its other independent variables, Mobile Banking Customer Perceived Value (Hypothesis 4), it appears that Mobile Banking Customer Perceived Value does not have a significant outcome on Customer Loyalty. Customer perceived value is proven to have a significant outcome on customer satisfaction in using Bank XYZ mobile banking, but this variable has no substantial outcome on loyalty. The benefit and sacrifice factor only affects customer satisfaction, but cannot encourage customer devotion.

In the Customer Satisfaction variable (Hypothesis 5), it appears that Customer Satisfaction has a substantial outcome on Customer Loyalty. Customers who are delighted, who feel happy, who feel that Bank XYZ mobile banking choice is the right and best one will have an effect on the loyalty of these customers in using Bank XYZ mobile banking. The customer satisfaction variable is a mediating variable that is significantly impacted by the independent variable of Mobile Banking Service Quality and Customer Banking Customer Perceived Value, which then significantly affects the customer loyalty.

Another thing that can be seen from the T test value of the Mobile Banking Service Quality variable and the Mobile Banking Customer Perceived Value of the Customer Satisfaction variable is the value of the Mobile Banking Service Quality (3.24) > value of the Mobile Banking Customer Perceived Value (2.28). This shows that Mobile Banking Service Quality has a more significant effect on customer satisfaction compared to Mobile Banking Customer Perceived Value.
The implication of this research is that Bank XYZin developing its mobile banking services must pay attention to elements in Mobile Banking Service Quality (Efficiency \& Convenience, Assurance \& Security, Reliability, Responsiveness) because it will affect customer satisfaction. Also Bank XYZ must pay attention to the benefit and cost factors associated with the Mobile Banking Customer Perceived Value variable which also affects customer satisfaction. Another thing is that Bank XYZ must assure that its customers are truly delighted with Bank XYZ mobilebanking services, because this variable is an important variable in determining customer loyalty. These loyal customers will provide more profit to Bank XYZ and provide references to more people related to Bank XYZ services, especially Bank XYZ mobile banking.

Along with the positive development of the smart phone market which is a mobile banking access tool, this opportunity must be captured by Bank XYZ to create a new market for Bank XYZ mobile banking users. Based on this research, when a customer decides to use mobile banking, it is not impacted by younger or older age factors, so that the offering/marketing of Bank XYZ mobile banking can be accomplishedto all Bank XYZ customers without exception. Bank XYZ also needs to observe the number of mobile banking users from its existing customers, where many customers who have long been Bank XYZ customers apparently have not used Bank XYZ mobile banking for too long. Bank XYZ in marketing strategies for Bank XYZ mobile banking services, in addition to paying attention to service quality and perceived value, also pays attention to the socialization of existing customers. Bank XYZ mobile banking can be said to have become one of the banking solutions that has been accepted by customers if seen from the high usage rate within 1 month.

\section{CONCLUSION \& FUTURE WORK}

Mobile Banking Service Quality variable consisting of elements of Efficiency \& Convenience, Assurance \& Security, Reliability, Responsiveness, and Mobile Banking Customer Perceived Value variables have a significant effect on customer satisfaction in using Bank XYZ mobile banking, but do not significantly affect customer devotion. The Mobile Banking Service Quality variable has a more substantial effect on customer satisfaction compared to the Mobile Banking Customer Perceived Value variable. Customer Satisfaction Variables that are significantly impacted by the Mobile Banking Service Quality variable and the Mobile Banking Customer Perceived Value variable, have a substantialeffect on the Customer Loyalty variable.

Further research can be affiliated to the dependent variable of customer satisfaction and customer loyalty in the use of Bank XYZ mobile banking, where other independent variables that may still be investigated besides Mobile Banking Service Quality and Mobile Banking Customer Perceived Values such as: switching costs, trust in brands, or e-trust in the use of Bank XYZ mobile banking.

Published By:

Blue Eyes Intelligence Engineering 
Other research can be developed with a research model similar to this research model, but related to other Bank $\mathrm{XYZ}$ digital banking services such as the Bank $\mathrm{XYZ}$ Keyboard, Bank XYZ Vira (via the Line application), or Sakuku products.

\section{REFERENCES}

1. Paul, J., Mittal, A., Srivastasv, G. (2018). Impact of Service Quality on Customer Satisfaction in Private and Public Sector Banks, International Journal of Bank Marketing, Vol. 34 Issue: 5, 606 622

2. Xin, W., Changzheng, H., Bing, Z., (2016), Relationship Between Customer Perceived Value and Loyalty of Mobile Banking, International Conference on Education, Management, Computer and Society, 1096-1099

3. McDougall, G. dan Levesque, T. (2000). Customer Satisfaction with Services: Putting Perceived Value into the Equation, Journal of Services Marketing, Vol. 14 No. 5, pp. 392-410.

4. Ling, M, G., Sook Fern, Y., Kah Boon, L,. Seng Huat, T. (2016). Understanding Customer Satisfaction in Internet Banking : A Case Study in Malaca, Procedia Economics and Finance, volume 37, 80 85

5. Lee, G.G., Lin, H.F.(2005). Customer Perceptions of eService Quality in Online Shopping, International Journal of Retail \& Distribution Management, Vol. 33 Issue: 2, 161 - 176

6. Parasuraman, A., Zeithaml V.A., and Malhotra A. (2005). E-S-QUAL: A Multiple-Item Scale for Assessing Electronic Service Quality. Journal of Service Research, February 2005, 7(3), 213 - 233

7. Sharma, G., Malviya, S. (2014). Exploring The Dimensions of Mobile Banking Service Quality, Review Business and Technology Research Vol. 4, No. 1, July 2011, 187-196

8. Warta ekonomi.co.id, 18 Januari 2017, Pengguna Digital Banking BCA capai 7 juta,

9. Hammoud, J., Bizri, M, Rima., Babu, E, Ibrahim. (2015), The Impact of E-banking Service Quality on Customer Satisfaction : Evidence from The Lebanes Banking Sector : SAGE Open July-September 2018: 1 12

10. Toor, A., Hunain, M., Hussain, T., Ali, S., Shahid, A. (2016). The Impact of E-banking on Customer Satisfaction : Evidence from Banking Sector of Pakistan : Journal of Business Administration Research, 5(2), 27-40

11. Zeithaml, V.A. (1988). Consumer Perceptions of Price, Quality, And Value: A Means-End Model And Synthesis of Evidence. Journal of marketing. Vol 52, 2-22.

12. 12 Hallowell, R. (1996). The Relationships of Customer Satisfaction, Customer Loyalty, and Profitability: an Empirical Study. International Journal of Service Industry Management. Vol. 7(4), 27-42

13. Jamal,. Nasser. (2002). Customer satisfaction and retail banking. An assessment of some of the key antecedents of customer satisfaction in retail banking. International Journal of Bank Marketing, July 2002, 20(4), $146-160$

14. Ali, A., Ratwani, B. (2017). Customer Satisfaction in Indian Bank : Problem and Solutions, International Journal of economics Research, 14(9), 69-76

15. Podkorytova, O., \&Malova, A. (2018). Linking customer satisfaction with financial performance: an empirical study of Scandinavian banks. Total Quality Management \& Business Excellence, 1-19.

16. Keisidou, E., Sarigiannidis, L., Maditinos, D.I., dan Thalassinos, E.I (2013). Customer Satisfaction, Loyalty and Financial Performance: A Holistic Approach of the Greek Banking Sector. International Journal of Bank Marketing, 259-288.

17. Oliver, R.L. (1999). Whence Consumer Loyalty?. Journal of Marketing. Vol 63(4_suppl1), 33-44.

18. Nyadzayo, M.W. dan Khajehzadeh, S. (2016). The Antecedents of Customer Loyalty: A Moderated Mediation Model of Customer Relationship Management Quality and Brand Image. Journal of Retailing and Consumer Services. Vol 30, 262-270.

19. Pakova, O.N., Poberezhnaya E.V., dan Nekhorosheva K.I. (2016) International Monetary and Credit Relations in Russia: Problems and Solutions. Ekonomika I Upravlenie: Problemy, Resheniya. Vol 12, 2832.

20. Rahman, A., Hasan, M., Mia, A., (2017). Mobile Banking Service Quality and Customer Satisfaction in Bangladesh: An Analysis, The Cost and Management, vol 45, 26-32.

21. Zavareh, B, Farnaz,. Md Ariff, Sh, Mohd., Jusoh, A., Zakuan, N., Bahari, Z, Ahamad. (2012). E-Service Quality Dimensions and Their
Effects on E-Customer Satisfaction in International Banking Services, Procedia - Social and Behavioral Science, volume 40, 441 - 445

22. Bowen, J., Chen, S., (2001), The Relationship between customer loyalty and customer satisfaction, International Journal of Contemporary Hospitality Management, Vol 13, issue 5, 213-217

\section{AUTHORS PROFILE}

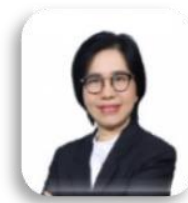

Elvriawati Tumewah, is a Senior Vice Presiden of a private bank in Indonesia. She has more than 25 years of experience in the banking area. She finished her bachelor degree from Trisakti University majoring in Architecture.

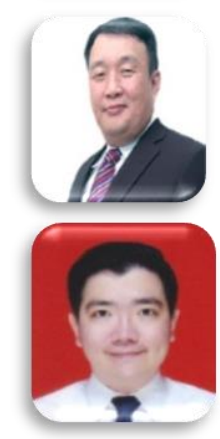

Juniarta, is the Head of Bandung Main Branch of a private bank in Indonesia. He has more than 20 years of experience in the banking area. He finished his bachelor degree from Trisakti University majoring in Industrial Technology.

Yonathan Kurniawan, is the Head of Kudus Main Branch of a private bank in Indonesia. He has more than 10 years of experience in the banking area. He finished his bachelor degree from Parahyangan Catholic University majoring in Industrial Technology.

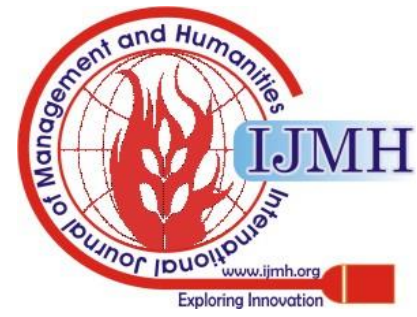

